\title{
Patriotism, place, and provisioning: assessing cultural ecosystem services through longitudinal and historical studies in Vietnam
}

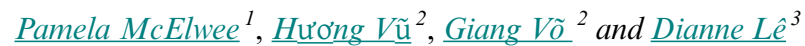

\begin{abstract}
Cultural ecosystem services (CES) provide multiple benefits to people, including experiences, identities, and capabilities through both material and non-material means. There have been few studies of CES in Vietnam, despite a number of historical, religious, cultural, and customary traditions that have long influenced landscape values and management. We aim to identify a range of CES important to respondents in a study site in north-central Vietnam by providing a unique longitudinal view. Over a two-decade period, different ecosystem benefits have been obtained by local households, some of which have been influenced by cultural factors or could be considered CES. These have included material ecosystem services, including agricultural production, local medicinal plants, and culturally relevant craft materials. There are also non-material CES of interest, including those related to sense of place and national identities, spiritual and religious practices, and recreational and aesthetic benefits. However, over time there has been diminishing importance of some material resources as landscapes have changed from a mix of agricultural lands and natural forests to plantation forestry, and social impacts have resulted from increased labor migration, which has diminished sense of place among younger generations. Assessing these changes allows us to explore how CES are not static or pre-given but shift over time and within different contexts.
\end{abstract}

Key Words: Asia; cultural ecosystem services; identity; rural development; sense of place

\section{INTRODUCTION}

Cultural ecosystem services (CES) are increasingly recognized as important benefits resulting from how people perceive, value, and use landscapes. The concept was first introduced in the Millennium Ecosystem Assessment (MEA), defining them as the (often intangible) "non-material benefits that people obtain from ecosystems" and outlining examples, ranging from recreational interactions with nature, sense of place, and aesthetic values to health and psychological benefits, learning and education, and spiritual and religious meanings (MEA 2005:58). Since then, the literature on CES has expanded rapidly; reports have delved into the networks and nodes in the growing field (Milcu et al. 2013), measurement principles to make them commensurable with other ecosystem services (Tengberg et al. 2012, Satz et al. 2013), and the relationship between CES and other academic fields (Daniel et al. 2012), among other topics. Cultural ecosystem services are considered an important component of the ways humans positively value their interactions with nature, which can translate into support for environmental policies, economic benefits through tourism and recreation, and direct social benefits like better health and well-being (Gould et al. 2019, Kosanic and Petzold 2020, Roux et al. 2020). Demand for CES is expected to continue to rise in coming decades, and thus is a key area for both researchers and policymakers to pay attention to and understand (Wolff et al. 2015).

How we identify and categorize different CES remains a challenging and active discussion. For example, recent work by the Intergovernmental Science-Policy Platform on Biodiversity and Ecosystem Services (IPBES) has suggested that the nonmaterial benefits of nature fall into categories of learning and inspiration, including education, knowledge acquisition, and inspiration for art and technological design; physical and psychological experiences, i.e., opportunities for physically and psychologically beneficial activities for healing, relaxation, satisfaction, recreation, leisure, and aesthetic enjoyment; and supporting identities, including religious, spiritual, and socialcohesion experiences, sense of place, purpose, belonging, rootedness, or connectedness, and basis for narratives and myths, rituals, and celebrations (Diaz et al. 2018). The authors point out, however, that these categories are broad and that diverse contexts will generate different classification systems in use locally; in other words, a single classification standard for CES is likely to be difficult. Further, some have argued that many of the concepts lumped into the idea of CES are associated with values, perceptions, and conceptualizations that cannot be well captured in terms like "cultural," "ecosystem," or "services" at all, given that these concepts emerge from biases toward anthropocentrism and scientism, rather than more contextual understandings of human-nature relationships (Kirchhoff 2019).

Despite these debates and critiques, most researchers have continued to associate CES with non-material, non-consumptive, and intangible benefits that arise from human interactions with ecosystems (Chan et al. 2012, Fish et al. 2016). For example, Russell et al. (2013) discussed different ways of experiencing nature, including knowing, perceiving, interacting and living with, yet without attention to "using" and "consuming" as possibilities to generate CES. Studies asking respondents to assess different ecosystem services commonly separate out CES from tangible benefits, like water provisioning or food (Pleasant et al. 2014). However, material ecosystem benefits are also strongly shaped by culture and values, and can also generate experiences and capabilities characteristic of CES (Chan et al. 2012, von Heland and Folke 2014, Bryce et al. 2016). For example, anthropologists have long investigated material goods and their uses as unique windows into different cultural and symbolic identities (Appadurai 1988). Material goods, ranging from food to housing to dress, can provide an important mediating role between worlds, are often imbued with symbolic resonance, and are important

${ }^{1}$ Rutgers University-New Brunswick, New Jersey, ${ }^{2}$ Central Institute for Natural Resources and Environmental Studies, Vietnam National University, ${ }^{3}$ Harvard University 
shapers of subjectivities. Most ecosystem benefits from nature are thus experienced through cultural worldviews and usually coproduced using anthropogenic assets, whether they are material or non-material (Díaz et al. 2018). As an example, production and collection of food within agroecosystems can be shaped by choices for provisioning of culturally preferred meals, shared labor in socio-cultural practices of collection, respect for future generations through seed saving, as well as co-producing reciprocal benefits back to ecosystems through preservation of biological diversity or soil carbon conservation. Thus, it makes sense to consider both material and non-material benefits arising from interacting with or using ecosystems as components of CES (Plieninger et al. 2015).

This approach fits with Fish et al. (2016), who introduced the idea of CES as constituted by interactions in specific places where cultural practices occur, and which result in benefits like identities, experiences, and capabilities. Identities are the ways in which nature helps people understand themselves and their communities; experiences are how events and contacts with ecosystems afford mental or physical benefits; and capabilities are how abilities to understand and do things are enhanced by ecosystems (Fish et al. 2016). This approach emphasizes that it is the underlying values given to nature that are potentially intangible and incommensurable, but that benefits like identities, experiences, and capabilities can derive from both material and non-material sources (Schnegg et al. 2014). This approach is also valuable in pointing out that services, benefits, and values can all change over time, whether due to ecosystem changes, socioeconomic shifts, or transformations in value systems. Thus, a more processual and dynamic interplay between humans and ecosystem services is preferred over seeing services as fixed processes and benefits as only end outcomes (Pröpper and Haupts 2014).

We use a case study in Vietnam to explore these issues and contribute to understanding how CES are shaped in dynamic situations encompassing both material and non-material services. There have been few studies explicitly engaging with CES as a concept in Vietnam, despite the country being a hotspot of biodiversity with long cultural traditions across a range of ethnic and cultural communities. Although many social scientists have pointed out important cultural knowledge and practices around ecosystem management, particularly for ethnic minorities (Condominas 1974, Århem 2009), there is relatively less attention to ethnic Vietnamese communities (known as Kinh) and explicit discussion of key concepts surrounding CES like values, identities, and capabilities. We examine a number of cultural ecosystem benefits in a study site in north-central Vietnam with Kinh villages and provide a unique view through the use of longitudinal data, including participant-observation, interviews, and surveys, with initial research carried out in 2001-2002 and a follow-up visit in 2019. Over this time period, different ecosystem benefits, influenced by cultural factors or impacting cultural preferences and subjectivities, have been enjoyed by local households. These benefits and the values underpinning them have shifted over time, highlighting that studies that pay attention to how and why experiences, identities, and capabilities may evolve and change can help in understanding the processual nature of CES.
For respondents in our study site in the province of Hà Tĩnh, key cultural benefits from ecosystems were both material and nonmaterial, ranging from culturally valuable foods, medicines, and other products, as well as the aesthetic and health values of landscapes. Many respondents also associated such landscapes with concepts of "homeland" and sense of place, and added to these feelings were nationalistic and patriotic symbolism linked to history, particularly around the origin of revolutionary heroes from these areas. Religious and spiritual values were also described by some respondents, especially older generations. However, changes over time have resulted in a diminishing importance of some CES, which have declined in importance as resources have been depleted and values have shifted. Changes in the physical landscape toward plantation forestry and highyielding agricultural crops has changed perceptions and values in both positive and negative ways. Additionally, high poverty rates in the area have driven families to send household members to work overseas in labor migration; the increasing reliance on remittances from laborers has led to less use of material resources from nearby ecosystems, as well as concerns that younger generations will not have the same sense of place for their homeland. Assessing these changes allows us to explore how CES are not static or pre-given, but shift over time and within contexts.

\section{BACKGROUND}

\section{Cultural ecosystem services (CES) in Vietnam}

Overall, there has been little work on CES in Vietnam to date, with only a handful of studies having addressed the topic explicitly (Table 1). Although many other authors have certainly discussed the cultural importance of ecosystem interactions and management in the past, they did not use the framing of CES per se to do so. For example, Indigenous knowledge is one cultural connection to landscape that has been explored in different communities in Vietnam (Nguyễn and Ross 2017, Sơn et al. 2019), but many others remain unstudied. This is particularly true for Kinh communities because existing studies of cultural landscapes and other literatures tend to focus on ethnic minorities and Indigenous peoples (Tekken et al. 2017).

Studies carried out in Vietnam that have drawn on CES concepts and literatures have identified cultural values associated with tourism, such as visiting beaches, walking, and other forms of recreation (Hồ et al. 2018a) as well as cultural services from gardens (Quyên et al. 2017). Some studies have also highlighted spiritual CES, including rituals conducted in important landscapes (Hồ et al. 2018a). There have been some studies of CES in agricultural production and values associated with rural landscapes, as well as concerns about declines in CES as modernization of agriculture has occurred (Berg et al. 2017, Tekken et al. 2017). Most of the work in Vietnam has been focused primarily on the Mekong Delta region, with other culturally important landscapes (mountainous areas, oceans, or islands) receiving less attention.

There are important ecosystem services with cultural dimensions in Vietnam that have been discussed outside of CES frameworks and not using these terms per se. For example, the cultural significance of garden and farm practices has been the subject of several studies (Trình et al. 2003, Vlkova et al 2011, Mohri et al. 2013), and there are ecological or environmental associations with 
Table 1.Previous cultural ecosystem services (CES) research in Vietnam.

\begin{tabular}{|c|c|c|c|}
\hline Authors & Subject of research & Region where carried out & Methods \\
\hline Tekken et al. 2017 & CES in rice landscapes & Countrywide & $\begin{array}{l}\text { Focus groups with farmers in four sites of rice } \\
\text { production }\end{array}$ \\
\hline Hồ et al. $2018 a$ & $\begin{array}{l}\text { CES for tourist landscapes in Hà } \\
\text { Tiên province }\end{array}$ & Mekong Delta & $\begin{array}{l}\text { Public participation GIS to map out travel to tourist } \\
\text { landscapes }\end{array}$ \\
\hline Hồ et al. $2018 b$ & $\begin{array}{l}\text { Recreation and tourism in U Minh } \\
\text { Thượng National Park }\end{array}$ & Mekong Delta & $\begin{array}{l}\text { Household }(\mathrm{HH}) \text { survey using Likert scale of } \\
\text { satisfaction with ecosystem services (ES) }\end{array}$ \\
\hline Quyen et al. 2017 & $\begin{array}{l}\text { ES in Hậu River system affected by } \\
\text { catfish farming, including CES }\end{array}$ & Mekong Delta & $\mathrm{HH}$ surveys of agricultural and aquacultural families \\
\hline Berg et al. 2017 & ES in Mekong Delta, including CES & Mekong Delta & $\begin{array}{l}\text { Farmer surveys to identify ES from agricultural/ } \\
\text { aquacultural landscapes }\end{array}$ \\
\hline Cormier-Salem et al. 2017 & $\begin{array}{l}\text { ES in Cần Giờ Mangrove reserve; } \\
\text { little specific on CES }\end{array}$ & Mekong Delta & $\begin{array}{l}\text { Small sample of interviews (five) plus biodiversity } \\
\text { sampling }\end{array}$ \\
\hline McDonough et al. 2014 & $\begin{array}{l}\text { Valuing different ES in Cần Giờ } \\
\text { Mangrove reserve }\end{array}$ & Mekong Delta & $\begin{array}{l}\text { Choice experiment with farming } \mathrm{HH} \text { on shrimp } \\
\text { production versus mangrove conservation }\end{array}$ \\
\hline
\end{tabular}

cultural festivals, such as whale worship ceremonies (Parnwell 2013) and with literary traditions (Lê 1999). Vietnam also has a few policies that are somewhat related to CES, although not explicitly. These include participation in the World Heritage Convention, with the designation of eight national sites as important cultural and environmental landscapes, including the Trang An landscape complex designating both cultural and ecological significance (Bùi et al. 2018, Thào and Pulliat 2019). Vietnam also has a nationwide program of payments for ecosystem services, which transfers money from users of services to those who provide them. One of the five main ecosystem services that is eligible for payments includes aesthetic landscape value for tourism enterprises, who are supposed to pay 1-2\% of their revenues as payment for environmental services (PES) to local governments, although this only happens in a few selected areas (McElwee et al. 2019). However, beyond this tourism component, the PES program does not incorporate other CES concepts nor attempt to value non-material benefits.

\section{METHODS}

\section{Site information}

The study was conducted in rural areas of Hà Tĩnh province, approximately $300 \mathrm{~km}$ south of the national capital Hanoi (Fig. 1) in a region known as the north-central coast. Hà Tĩnh had an estimated population of nearly 1.5 million people in 2019 , and the province has long been considered to be one of the poorest areas of the country. The area is geographically characterized by low coastal plains bordering the East Sea, rising to high mountains separating Vietnam from Laos. Historically forest production has taken place in hills and agriculture in lowlands, and two important national nature reserves, Vũ Quang National Park and Kẻ Gỗ Nature Reserve (KGNR), were demarcated in the 1990s to protect biodiversity; however, much of the forest area even in reserves is heavily disturbed due to past logging. Some 50,000 ha of lands considered "degraded" in the province were converted to acacia plantations between 2000 and 2014 (Lã et al. 2016).

The research was undertaken in five villages located in the Cẩm Xuyên district in the buffer zone of KGNR, a state-designated protected area surrounding the man-made irrigation reservoir known as Lake Kẻ Gô̂. Approximately 40,000 people lived in the buffer zone of the park at the time of the work in 2001, although in reality this created no significant restrictions on land use. The study villages, which were all ethnically Kinh, were chosen to provide a range of dependence on the KGNR, with several villages directly on the border and some farther away. Each village had a total number of households ranging from 75 to 135 . Villages usually consisted of a core of houses, surrounded by rice and other crop fields, rising to upland forests at the fringe, some of which were within KGNR boundaries. These areas were used in 2001 for collection of timber, fuelwood, and a variety of nonwood forest products (NWFP), as well as buffalo and cattle grazing. Over time, stricter management of the borders of the KGNR by ranger patrols and interdiction efforts on timber extraction and hunting had reduced use of the park by locals by the year 2019 .

\section{Study sample and methods}

Villages were originally visited beginning in November 2000 until October 2001 in the first round of research, during which the first author carried out participant observation, focus groups, and key informant interviews. Additionally, a standardized survey was carried out with a random sample of $20 \%$ of households on each village's census rolls (using a random number between 1-10 selected from a hat by the headman to be the first household selected, and then every $k$ th household), for a total of 104 households. Household information collected included size, income, migration status and history, land tenure holdings and access, agricultural production, and local knowledge and use of ecosystems. Checklists of the main categories of ecosystem goods and services used were compiled from focus group meetings that were held prior to the survey in eleven villages total (the five survey villages plus six others in the buffer zone) and used as prompts to aid in memory recall (see McElwee 2008, 2010). More than 300 plant voucher specimens were taken from gardens, fields, and nearby forests and deposited at the Institute of Biogeography's herbarium in Hanoi and identified by a botanist specializing in central Vietnam.

In July 2019, the first, second, and third authors returned to the area for follow-up work. Out of the original 104 households, 91 were able to be re-interviewed (however, the people originally interviewed were not always available; e.g., sometimes in round two, adult children living in the household of those who had 
Fig. 1. Map of study area.

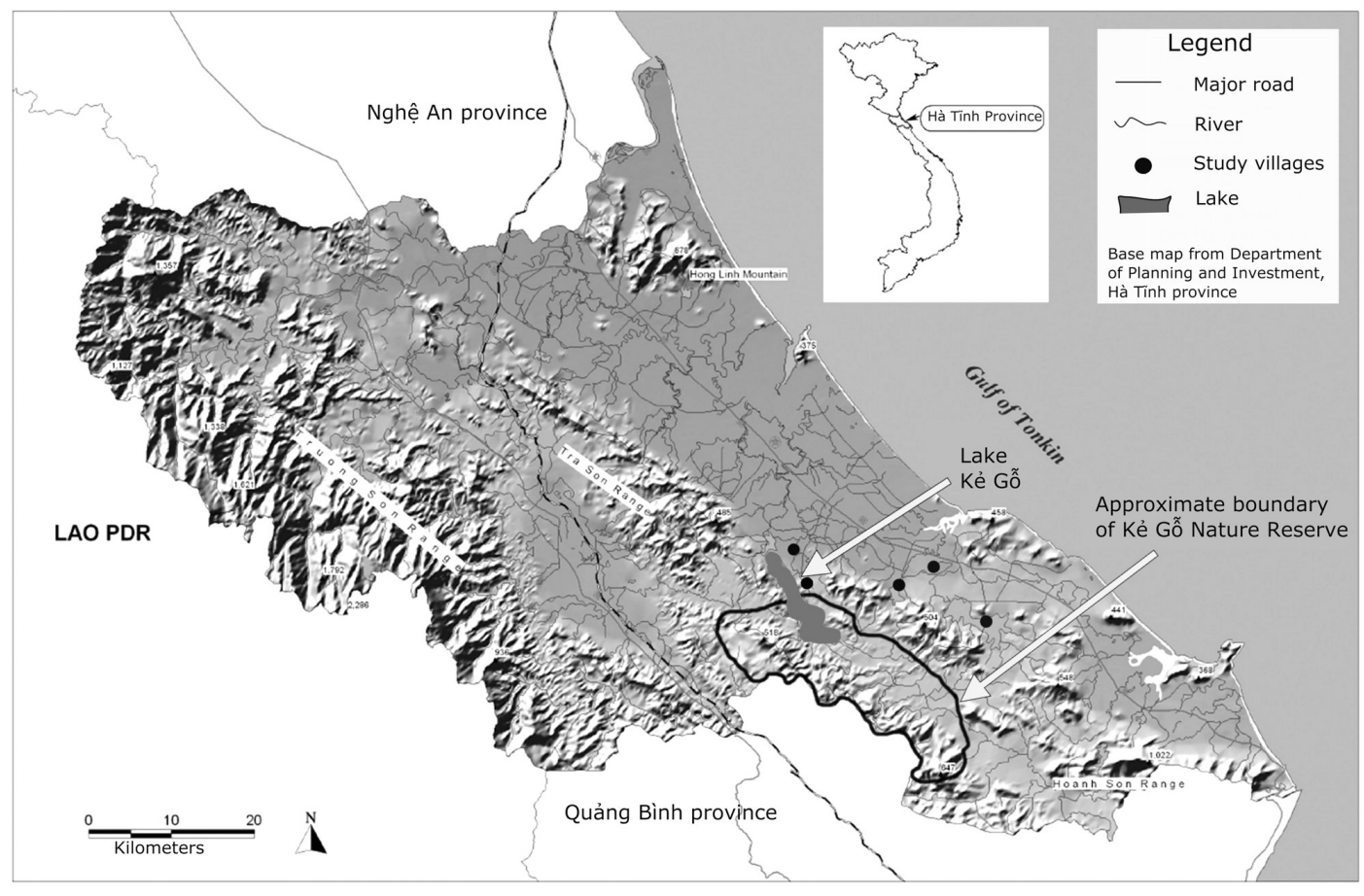

originally been interviewed supplied information). Those who were not able to be interviewed had in most cases moved away or died, while several were unavailable at the time of the resurvey. In the second round of surveys, households were asked about important changes in household economies, land use, and livelihoods in the past two decades. We also added a new set of questions specifically on ecosystem services, including CES, in which households were asked which local ecosystem services were most important and how they perceived use and benefits to have changed over time. There were also open-ended questions allowing respondents to identify key ideas or phrases they associated with "sense of place" and "benefits from nature". We also conducted key informant interviews with the five village headmen, in which we discussed historical changes in ES use in particular.

For our analysis, we focused on descriptive statistics from the surveys, as well as qualitative information from interviews and focus groups to provide a sense of the breadth of different ways to think about CES across multiple benefits within our study area. Because we are interested in tracking trends (e.g., changes in what CES/ES were used) rather than trying to associate particular variables (such as socioeconomic status) to CES/ES use, we have used a combination of historical, narrative, and descriptive statistic approaches. There was also not much variation in the responses around CES use in the 2019 panel survey questions, therefore we have focused on this analysis of trends over time rather than factors explaining CES use.

\section{RESULTS}

There were two broad categories of benefits from nature and landscapes related to CES in Hà Tĩnh that survey respondents and focus group participants enumerated: material and nonmaterial benefits. These categories were derived from the literature because we did not ask respondents to group ES benefits but to simply enumerate those considered most important. Material benefits included food production, medicinal plant use, and craft materials for culturally important items. This list confirmed previous surveys of the area. For example, in a study of the nearby KGNR done by ethnobotanists in 2000, 295 species of plants were recorded, of which interviews revealed 109 medicinal plants, 13 used for crafts and other products, 11 kinds of wild-collected foods, and 42 useful for construction materials (Trần and Phạm 2000). All of the material benefits from provisioning ES also helped shape different experiences, identities, and capabilities. Additional non-material benefits included spiritual and religious beliefs and practices, sense of place and patriotism, and aesthetic and recreational enjoyment of landscapes.

Variation across households in what material benefits they derived from ecosystems correlated with income (both total amounts and sources) and with labor availability in 2001. The first author has published quantitative analysis elsewhere on use of provisioning ecosystem services across income classes and so we do not repeat these findings here (McElwee 2008, 2010). Non-material benefits revealed much less variation because the large majority of households surveyed in 2019 were able to list several CES they obtained from nearby areas and primarily pointed to widespread agreement on broad categories of benefits. However, the uses, understandings, and values associated with different ES have shifted over time (Fig. 2). These changes in ES interactions have arisen in response to environmental changes (both diminishing supplies of some ES as well as new sources of others), governmental policies (such as restrictions on religious practices 
Fig. 2. Timeline of changes in ecosystem services (ES) and cultural ecosystems services (CES) use.

\begin{tabular}{|c|c|c|c|}
\hline $\begin{array}{l}\text { High dependency on material } \\
\text { ecosystem services (ES) } \\
\text { Extensive use of many provisioning } \\
\text { ES: housing materials (timber, palms, } \\
\text { bamboo); food (production and } \\
\text { collection in forests); dyes for } \\
\text { clothing; medicinal plants (wild } \\
\text { collected). Some planting of valued } \\
\text { species in gardens. }\end{array}$ & & $\begin{array}{l}\text { Shifts in ES kind and availability } \\
\text { Continued use of provisioning ES and } \\
\text { expansion into markets for timber, } \\
\text { charcoal, and fuelwood. Markets for Non- } \\
\text { timber forest products (NTFPs), but } \\
\text { declines in availability over time due to } \\
\text { overharvesting. Declines in local cultivars } \\
\text { for production of rice and other } \\
\text { foodstuffs; shifts to high-yielding variety } \\
\text { (HYV) and industrial cassava production. }\end{array}$ & \\
\hline $\begin{array}{l}\text { Non-material cultural ecosystem } \\
\text { services (CES) } \\
\text { Practices of geomancy, building of } \\
\text { religious shrines and temples, } \\
\text { religious practices and beliefs tied to } \\
\text { landscape (rivers, mountain spirits). }\end{array}$ & 1970s-1980s & $\begin{array}{l}\text { Non-material CES } \\
\text { Reemergence of some cultural practices, } \\
\text { including mother goddess religion. } \\
\text { Building of war shrines and more } \\
\text { possibility for travel and tourism as } \\
\text { economy improves and more time for } \\
\text { recreation. }\end{array}$ & 2010s-now \\
\hline pre-1960s & $\begin{array}{l}\text { Expanding and changing use of material } \\
\text { ES } \\
\text { Rice production expands as forested areas } \\
\text { cleared and more extensive irrigation built. } \\
\text { Increased importance of gardens given } \\
\text { failures of collective agriculture. Medicinal } \\
\text { plants sold to processing factory for } \\
\text { export. } \\
\text { Non-material CES } \\
\text { Patriotism at conclusion of war, pride in } \\
\text { new landscapes (Kẻ Gố Lake), but declines } \\
\text { in overt religious practices like rituals due } \\
\text { to government discouragement. }\end{array}$ & 1990s-2000s & $\begin{array}{l}\text { Decline in material ES use and shifts to } \\
\text { other forms of income } \\
\text { Little collection of NTFPs as acacia forests } \\
\text { expand and remittances grow in importance. } \\
\text { Decline in use and availability of medicinal } \\
\text { plants due to loss of knowledge. Worries } \\
\text { about loss of "sense of place" among } \\
\text { younger generation. } \\
\text { Non-material CES } \\
\text { Rising prosperity allows for travel and } \\
\text { tourism, promotion of local sites as } \\
\text { historical and patriotic locations for } \\
\text { pilgrimages. Use of Kẻ Gố Lake for } \\
\text { aesthetics and recreation. Concerns about } \\
\text { pollution in landscape and interest in } \\
\text { regreening "homelands." }\end{array}$ \\
\hline
\end{tabular}

or collectivization of agriculture), and global economic change (including the rise of overseas labor migration and remittance economies).

\section{Material benefits and cultural ecosystem services (CES)}

\section{Agriculture}

Cultural preferences for subsistence foods like rice strongly influenced agricultural production in Hà Tĩnh. $94 \%$ of all families surveyed in 2001 produced rice, which constituted about onequarter of the household income, while in 2019, $96 \%$ of households still planted rice. Rice growing in north-central Vietnam is challenging given environmental factors (poorer soils, more extreme summer temperatures, and less access to water), which has contributed to lower rice productivity than in the country's two main deltas in the north and south; local production was around $3600 \mathrm{~kg} / \mathrm{ha} /$ per crop in 2001, rising to on average 5500 $\mathrm{kg} / \mathrm{ha} /$ per crop in 2019 . However, rice continued to be cultivated because of cultural preferences and values. These values included preferences for rice as the staple basis for most meals (not having rice at a meal was rare) as well as taste preferences for specific local varieties. Despite a nationwide shift to improved rice varieties, particularly high-yielding and hybrid, traditional varieties have remained in use under drought-prone or rainfed conditions; this was the case in the case study area, where $40 \%$ of farmers surveyed in 2001 still planted at least one traditional variety because it was seen as more adaptive to local conditions (Fig. 3a). Cúc nhanh, a local variety that could be planted either in the summer-fall crop or as a one-season rainfed crop, was most common.
Fig. 3. Culturally important material ecosystem services in Hà Tĩnh, Vietnam. 3a. Rice paddy field, 2001; 3b. Drying medicinal plants, 2001; 3c. Storehouse of leaves for making conical hats, 2001.

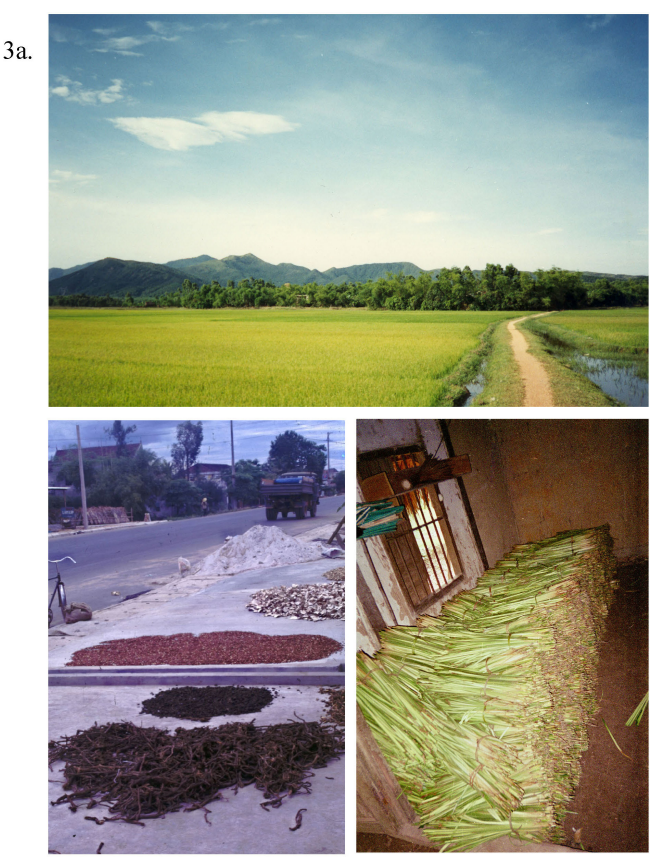


For many households, rice production conferred a sense of identity, giving a historical continuation with practices of generations past, and interviewees made references to forebearers also being farmers as a reason for why they continued to do so. Rice production also afforded opportunities for social capital building through labor exchanges with neighbors and sharing of rice if needed. For example, $85 \%$ of households in 2001 noted that they regularly exchanged labor with neighbors and kin (McElwee 2007). These social ties and exchanges around labor also gave rise to important cultural artifacts, namely poetry and songs that were created and sung while working in fields, and for which this region is well-known. For example, rhyming couplet folk songs known as Ví and Giặm, sung in teams of men and women while sharing labor in rice fields, were recently recognized by UNESCO as important intangible heritage of Vietnam (UNESCO 2014). Many of the songs reference local landscapes and weather in ways both humorous and nostalgic (Đào 1998).

Beside rice production, which took place in fields away from the household compound, all families interviewed had at least a small home garden as a source of supplementary non-rice foods and potential income as well because extra fruit and vegetables could be sold at a nearby market. These gardens were particularly important in the 1970s and 1980s when households worked collective rice fields as part of socialist cooperatives; poor production and unequal shares meant that many households turned to individual home gardens to provide sufficient food to eat. Home gardens surveyed in 2001 usually consisted of an understory of ground crops like potatoes, peanuts, or cassava, surrounded on the edges by fruit and fuelwood trees, which also served as shade. Small plots for vegetables were often located near the kitchen, and often excess given away to neighbors and relatives to confirm social bonds. Most households also had plots for tea bushes, as well as sheds for livestock. This integrated agroforestry system is known in Vietnam as VAC, for Vườn Ao Chuồng (garden, pond, livestock sty) in which inputs into one (e.g., sweet potato vines for pigs) cycle to another part (e.g., animal manure for fertilizing vegetables; Trình et al. 2003). By 2019, households noted that although their gardens remained important for aesthetic reasons and for sharing with neighbors, they were less useful for sources of cash income, which was being supplied more regularly by remittances.

\section{Medicines}

Local landscapes have long supplied sources of traditional medicines, known as thuốc nam (medicine of the south) to distinguish it from traditional Chinese medicine; the thuốc nam pharmacopoeia uses local plants from Vietnam's more tropical climate. Traditional medicine is a strongly culturally inflected practice and was further conditioned during the wars for Vietnamese independence when Western medicines such as antibiotics were in short supply. In the 1960s onward, people were encouraged to use local plants because they were easy to obtain, and each family was urged to have an assortment of basic plants in their gardens to treat a variety of common ailments (Bùi 1999).

Starting in the $1980 \mathrm{~s}$, medicinal plants were collected commercially in the area, due to demand from a pharmacy in Hà Tĩnh city, $40 \mathrm{~km}$ away. The pharmacy supplied much of the traditional medicine for the province in the form of thuốc $b$ ổ (prepackaged tonics) as well as the capital, Hanoi. When trade resumed with China after the 1979 war, the Chinese market became the main destination for Hà Tĩnh's medicinal plants, and many were overharvested in the late 1980s and early 1990s. Some $20 \%$ of the families interviewed in 2001 collected wild medicinals in nearby forests or shrublands, some of which were sold to a local medicinal plant cooperative, which in turn sold to the larger urban pharmacy (Fig. 3b). But by 2019, households indicated that wildcollected medicines were nearly depleted, and the local buyer no longer operated. Personal use of traditional medicines still remained important, despite increasing access to Western sources. Most household gardens had small numbers of medicinal plants grown for their healing properties, and households still also occasionally wildcrafted medicinals from nearby forest lands.

\section{Crafts}

Cultural traditions have influenced the collection of material ecosystem benefits, although demands have shifted over time. For example, củ nâu, local name $n u$, used to be a major commodity of the study area earlier in the 20th century. Prior to the Vietnam War, most peasants made their own clothes, and củ nâu dyed them a deep brown, a culturally favored color; the local area was wellknown for producing roots of very high-quality and rich color. Củ nâu (Dioscorea cirrhosa) was originally found in forested areas, and eventually, in the mid-20th century, people began planting wild tubers in their gardens. However, as cotton and linen peasant gowns gave way to Western styles and army uniforms favored by military leaders, the demand for dye dropped, although a number of gardens still had plants growing in 2001.

Another culturally distinctive craft product derived from local forests were palm leaves to make conical hats (known as nón lá). Leaves were harvested from a small palm, Lanonia centralis, known as lá nón, or locally as lá toi, meaning "the covering leaf" (Henderson and Bacon 2011). The palms were found primarily in understory of secondary forests and were harvested yearround, particularly coinciding with slack agricultural seasons. Leaf collecting appealed to many because the leaves were easy to find and collect, requiring only a knife and a bag; the light weight meant that women and children could readily be collectors. In the late 1990s, one woman set up a leaf collecting cooperative to which local collectors could sell by the bundle, which were then trucked in bulk to conical hat-making villages in the north (Fig. 3c). Palm leaf collecting was done by $52 \%$ of households in 2001 , primarily by women, and contributed up to $20 \%$ of the total household income for many families, often used for school fees and supplies for children. Based on figures collected in 2001, around five million leaves were harvested each year from the district for the hat trade. However, this figure had dropped significantly by 2019 , because the income from leaf collecting was now considered too marginal to undertake the labor; only $2 \%$ of households mentioned still harvesting, and at lower amounts than previously. Households that needed extra income were far more likely to send a family member abroad, particularly youth, as migrant labor (such as to factories in Taiwan and South Korea) than collect lowvalue forest products.

\section{Non-material benefits and cultural ecosystem services (CES)}

In our study site, we noted three major categories of CES benefits that were not tied to material consumption or benefits of ecosystems: sense of place, spirituality and religious practices, and aesthetics, health, and well-being. 
Table 2. Responses to survey questions on cultural ecosystem services (CES), 2019.

\begin{tabular}{|c|c|c|}
\hline Type of CES & $\begin{array}{l}\% \text { responding that CES } \\
\text { was seen positively or } \\
\text { negatively }\end{array}$ & Additional descriptions provided \\
\hline \multicolumn{3}{|l|}{ Sense of place } \\
\hline \multirow[t]{4}{*}{ Pride in native place } & $80 \%$ positive & \multirow[b]{2}{*}{$\begin{array}{l}\text { Most distinctive feature mentioned: } \\
\text { Lake Kẻ Gỗ and other water features }(37 \%) ; \cdot \text { Revolutionary memorials } \\
(23 \%) ; \cdot \text { Natural features (birds, nature; clean air; } 14 \%) ; \cdot \text { Improved economies } \\
(14 \%) ; \cdot \text { Other created landscapes (gardens, etc.; } 7 \%) ; \cdot \text { Other (quality of } \\
\text { people, etc.; } 2 \%) ;\end{array}$} \\
\hline & & \\
\hline & $20 \%$ negative & Negative features: \\
\hline & & $\begin{array}{l}\text { "Nothing special here.". "Nature here is too dry - don't like it.". "We have } \\
\text { nothing!". "Used to have beautiful forests here but gone now.". "Don't even } \\
\text { have a place to play for kids.". "It's too difficult here, we struggle a lot.". } \\
\text { "Not yet as developed as one would like." }\end{array}$ \\
\hline \multicolumn{3}{|l|}{ Aesthetics, recreation, and health } \\
\hline \multirow[t]{2}{*}{ Feelings regarding forests } & $96 \%$ positive & $\begin{array}{l}\text { "refreshing". "places to rest". "beautiful". "comfortable". "greenness". } \\
\text { "water banks and birds singing". "no blazing heat". "spiritual significance } \\
\text { due to temples". "more green". "even some deer to see" }\end{array}$ \\
\hline & $4 \%$ negative & $\begin{array}{l}\text { "Nothing different about forests." "We never go to the forest.". "Forest } \\
\text { work is hard." }\end{array}$ \\
\hline \multirow[t]{2}{*}{ Feelings regarding nearest urban area } & $88 \%$ negative & $\begin{array}{l}\text { Cities considered " "dirty". "loud". "noisy". "too hot". "irritating". "no wind and no } \\
\text { trees". "dusty". "crowded". "no animals". "not enough trees". "air in cities is } \\
\text { suffocating" }\end{array}$ \\
\hline & $\begin{array}{l}2 \% \text { positive, } 10 \% \text { no } \\
\text { answer/don't go to cities }\end{array}$ & $\begin{array}{l}\text { "The economy in cities is higher." "Cities have things to buy". "There are } \\
\text { things to do in cities.". "There is high rise housing.". "Have a lot of cars.". } \\
\text { "Can be fun." }\end{array}$ \\
\hline $\begin{array}{l}\text { Other additional mentions of positive } \\
\text { feelings regarding local landscapes in } \\
\text { general }\end{array}$ & & $\begin{array}{l}\text { "Rural village air is refreshing, clean.". "Rural areas are more spacious and } \\
\text { wide."."Comfortable, quiet, refreshing, good weather."."Clean, spacious, } \\
\text { and refreshing." "More comfortable, more peaceful.". "Natural in the } \\
\text { outdoors." }\end{array}$ \\
\hline
\end{tabular}

\section{Sense of place}

Sense of place was an important concept for many households, often expressed through the word quê hương (homeland or native place; Fig. 4a). The concept indicates one's origin place, often traced back to a paternal ancestor: when meeting people for the first time, people are often asked "what's your homeland? (quê hương ở đâu?)." In previous decades, a quê hương was where a person was a member of a village roll and paid taxes and registered land, and had family altars commemorating ancestors (Hardy 2003). The concept of quê hương remains particularly tied to rural spaces and landscapes for Kinh people; many people born in Hanoi, for example, will state that their father or grandfather's rural birthplace is their homeland, even if they've never lived there, making a quê hương an important marker of identity (Karis 2013). Many of the well-known folk songs from the north-central region refer to unique elements of life in the landscape, from the feel of rain to smell of soil, helping to create a sense of homeland (Phạm 2018).

In the 2019 survey, we asked respondents to describe how they felt about their local quê hương. Around $80 \%$ of respondents agreed with the statement that "they felt pride in their native place," with the rest responding that it was "just average" or a "struggle to survive" there, in several respondents' words (Table 2). Those who expressed pride were asked to elaborate on what they thought was distinctive about their homeland, or what they talked about to others. The most numerous answer (from $37 \%$ of respondents) was the Lake Kẻ Gỗ area, a man-made reservoir for irrigation, with some mentioning pride in the fact that the lake was constructed by local workers and the army over nearly 4 backbreaking years (1976-9) and completed earlier than
Fig. 4. Non-material cultural ecosystem services in Hà Tĩnh. 4a. Sense of place (Cẩm Sơn village, 2019); 4b. Garden shrine with offerings, 2001; 4c. Temple to Lê Duẩn at Kẻ Gỗ Lake, 2019.
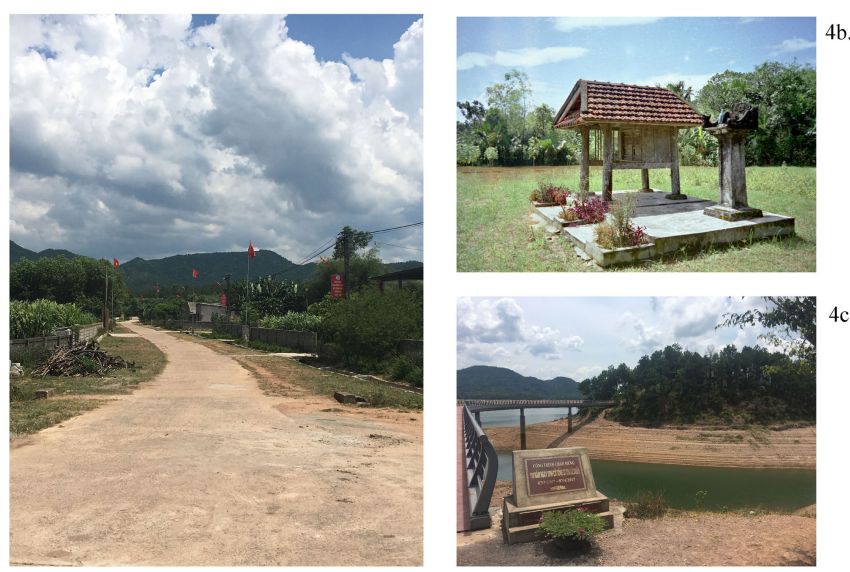

4 a.

scheduled. The labor efforts were reflected in a nationally popular song celebrating the construction called Người đi xây hồ Kẻ Gô̂ (The People Who Built Lake Kẻ Gỗ) that was regularly remixed in karaoke and on YouTube videos.

For many respondents, the concepts of "sense of place" and "pride in homeland" were tied up in memories and commemorations of political and revolutionary work, a legacy of Vietnam's long wars for independence from 1945 onward. 
Some $23 \%$ of respondents mentioned specific memorials for deceased revolutionary leaders, including former national Party Secretary Lê Duẩn (a memorial was constructed in 2017 to him on the edge of Lake Kẻ Gỗ, see Fig. 4c), anti-colonial revolutionary Hà Huy Tập (born in the district and executed by the French in 1941), and Nguyễn Đình Liê̂n (a founder of the Communist Party of the district executed by the French in 1931). Each of these leaders had a particular place (commemoration site, tomb, or temple) located nearby, and these sites often combined cultural elements (constructed buildings and worship altars) with natural ones (tree groves, bamboo stands, ponds, etc.).

Only $14 \%$ of respondents associated solely natural features to their quê hương, ranging from "green trees and yellow leaves" to "regenerating forests" and "birds singing." Seven percent of respondents mentioned home gardens. Other positive answers included "friendly neighbors" to "improved roads." The remaining $20 \%$ of respondents answered in the negative, in particular that there was nothing to be proud of.

Spirituality and religious cultural ecosystem services (CES)

There were some important CES related to spiritual beliefs and practices linked to landscapes and the environment. Like much of the rest of Vietnam, religion was an eclectic mix of Buddhism, Confucianism, Daoism, and ancestor worship. In the past, each village often had one or more cult committees, which were responsible for rites honoring various village deities (thần thành hoàng) who were selected to serve as protective spirits, ranging from legendary heroes to lowly bandits (Bùi 2000). Some of these guardian spirits were associated with particular landscapes. For example, one study village had a small temple to honor a wandering Chinese trader who had appeared in the area in what was probably the 16th or 17 th century, and who was said to have great healing powers and identified many herbal remedies from local plants. Another village had a temple to the founding ancestor ( $h o \underline{\text { tộ }} c$ ) of the village as well as a temple for the worship of Princess Liê̂̃u Hạnh, an important figure in the folk religion known as mother goddess worship. Both temples were associated with sacred elements of water and had been built at the head of the Rào Cái river in the beginning of the 19th century (the lower river was dammed to create Lake Kẻ Gỗ). Several other outdoor shrines could be found dotted in various areas around the KGNR for spirit worship, particularly near entrance paths; these shrines were a place to burn incense and leave offerings for spirits, and to ask for their help in avoiding dangers in the forest (such as accidents or diseases).

In addition to communal spirit worship, local cultural practices also involved domestic ancestor worship, which had components associated with the natural environment as well. Ancestor altars were kept inside the home in a propitious location, determined through geomancy (phong thủy, literally wind and water, also known in English as feng shui). Most households also took pains to situate any new home that was built according to correct environmental principles and correct calendar times laid down by a geomancer (thầy địa lý) or fortuneteller (thầy bói). Geomancy was useful in situating houses to take advantage of environmental conditions, such as the practice of orienting doorways to maximize breezes given the absence of air-conditioning. Tomb placement for deceased family members was also guided by geomancy, to ensure a location and alignment that the relative would prefer in their afterlife. A number of households also built a small altar outside, usually consisting of a platform on which a small concrete house sat (Fig. 4b). Tea and rice wine, along with pots of incense sticks, would be offered, as well as flowers that might be in bloom in the home garden, such as hibiscus. This practice was explained as complementary to that of ancestor worship. One's ancestors were the spirits of the domestic sphere and governed life inside the house; outside spirits should be propitiated with an altar outside the house. These spirits included spirits of the earth (thần đất $)$, of the sky (thần trời), and the spirits of Buddhist personages who wandered the earth. These spirits were often asked for help at the beginning and end of rice seasons, and during times of bad weather and droughts.

\section{Aesthetics, recreation, and health}

Other locally valued CES benefits were related to aesthetics. Of the survey respondents in $2019,96 \%$ had positive feelings toward forest landscapes in the area, with many positive comments regarding health, shade, and beauty (Table 2 ). The few who did not agree about the benefits said they either did not go to forested areas, did not answer, or believed "there's nothing special about forests." In another survey question asking households to make comparison to the nearest urban area (a provincial town), $88 \%$ of respondents said that they preferred their local village. In general, cities were considered "dirty," "noisy," and with few environmental amenities. Those who had positive views felt that cities "have more regulations on trash so they are cleaner now" and "there are things to buy and things to do" there. In an openended question allowing participants to discuss their most positive feelings toward local landscapes, households mentioned "more trees," "fresher air," "peacefulness," "more comfortable," and "better climate" as general answers.

Households also indicated that home gardens served as an important source of aesthetic pleasure, a finding first noted in 2001 that continued in 2019. Many families cultivated ornamental plants, particularly around the house and on the path to the door, to provide color and enjoyment, including dừa cạn (Catharanthus roseus (1.) G. Don), xương (Tradescantia spathacea $\mathrm{Sw})$, dâm bụt (Hibiscus rosa-sinensis L.), and hoa hồng (Rosa spp.). Some families hung wild orchids collected in nearby forests. Homes also often incorporated ponds and other water features both for the practicality of raising fish as well as aesthetic enjoyment and spiritual fulfillment. These gardens were considered an important spot for calm and peacefulness. The aesthetic appreciation of gardens was also related to health and well-being. This part of north-central Vietnam was well known for being extremely hot in summer, as well as prone to drought, and shade was often at a premium. Shade could be acquired through planting fruit trees in the garden around a home, particularly behind the house to cool the inside. Shade was also important along walkways and paths (although as motorbike usage has risen in the past 20 years walking along village lanes was less common in 2019 than it used to be). The presence of afforested acacia hills near villages, which had been planted over the past two decades, were mentioned by respondents as one reason why the area seemed shadier and greener than in the past, and that dust and dirt seemed to have decreased from previous decades (the paving of roads was also attributed). 


\section{Drivers of historical change in ecosystem services (ES) benefits} The changes in ES interactions that were observed between the two study periods (and which households discussed in their assessment in 2019 of what had changed most in the past two decades) included shifts in types of ES/CES used, where they were obtained, and how they were valued (monetarily or otherwise). Residents noted in 2019 that both environmental change and social changes contributed to the shifts in CES benefits that were valued at different points in time. Degradation of natural forests both inside and outside the KGNR since the 1990s had led to the loss of medicinal plants for use and sale, as well as declines in overall biodiversity. The expansion of planted forests since 2000, primarily acacia harvested for wood to supply pulp and paper mills, has brought both positive and negative benefits. For many households, the additional income was welcome and was less onerous than previous foraging trips into the natural forests had been. The plantations also provided a greener landscape, more shade, and less dust for many respondents who appreciated the shelterbelt properties. However, other households noted that acacia plantations did not have the same ecological structure as natural forests, with no undergrowth, no diversity of plants (such as medicines or ornamental flowers for enjoyment), and little aesthetic reason to walk there.

The other major factor mentioned as contributing to social changes in the past two decades was the rise of overseas labor migration (đi lao động) from the district. In 2001, fewer than onequarter of households had a member who sent remittances home, nearly all of which were domestically employed (primarily in Ho Chi Minh City or Hanoi). By 2019, 52\% of respondents were receiving remittances, many now acquired overseas, and which provided significantly more income (several thousands of dollars a year or more). The growth of industrial parks throughout Asia had drawn many young people to work overseas, as have formal government programs that encouraged households in poorer areas to send younger generations to work abroad on multiple year contracts.

Most households that had significantly relied on NWFP collection for household cash income in 2001 had substituted migrant remittances and no longer collected. This change was consistent with findings in 2001 that the use of provisioning ES was mainly predicted by access to alternative occupations (e.g., households with members earning wage labor or business income had less use and dependency on provisioning ES; McElwee, 2008). As youth left for work overseas, there was some concern about loss of transgenerational knowledge transmission, although this was outweighed for most by a sense of financial security that such employment provided. However, it was clear that older households had greater ecological knowledge. For example, although the average number of species in a garden was 41 in the 2001 survey, the only households with over 100 species in their gardens were several older households (average age over 75).

\section{DISCUSSION}

We discuss below key findings from the work in Vietnam and point out some lessons to further recognize and value CES, as well as to improve management of landscapes that provide CES. Returning to the idea of CES as being a product of environmental spaces and cultural practices, we note that the benefits received in our study sites should not be seen only "as a priori products of nature that people utilize for a particular benefit to well-being but rather as relational processes and entities that people actively create and express through interactions with ecosystems" (Fish et al. 2016:211).

\section{Indivisible material and non-material cultural ecosystem services} (CES) from natural and man-made landscapes

Most literature on CES describes them as mostly intangible and non-material benefits (Chan et al. 2012). However, as we have noted, residents of Hà Tĩnh enjoy many benefits from nature and landscapes that are both tangible and intangible, and it was difficult for respondents to separate out these categories. For example, rice has meaning beyond food production alone (a material ecosystem service). Planting rice is a practice that also provides a sense of security (the ability to store rice as a savings account), reflects culturally preferred tastes (as in the use of local varieties), links to historical practices (continuing practices started by previous generations), and which provides health benefits (in the form of nutrition). Further, local rice varieties were not only culturally preferred for their taste and cooking profiles, but these varieties also were ecologically adapted to the drought and high wind conditions in the area, requiring fewer pesticides and fertilizers to plant, indicating that practices or landscapes with high CES value may also have high value for other ecosystem services.

Our results also indicate that man-made or co-produced landscape features, in addition to natural ones, were important in providing CES. Such a finding confirms the point that CES are often derived from a particular place, not just an ecosystem in general (James 2015). Individual gardens around homes were an important created space generating multiple CES. Another major landscape that households considered important was Lake Kẻ Gỗ, a man-made reservoir. The lake provided scenic views and places to picnic or walk along the shores (recreational and aesthetic CES), as well as being the major source of irrigation for rice production (water regulation). In addition, it was a source of local pride that demonstrated values of hard work and collective action (supporting identities CES).

\section{Experiences, capabilities and identities in relation to cultural ecosystem services (CES)}

Using a framework of benefits related to experiences, identities, and capabilities that can be generated from ecosystems provides a helpful way around the material/non-material services divide. Many factors go into producing social-cultural identities, and in Hà Tĩnh, multiple elements of nature contributed to sense of self in relation to family, community, and national ties. The selfsufficiency demonstrated by planting and using medicinal plants from a garden, for example, contributed to a sense of independence in being able cope with wartime medical needs, as well as to have alternatives to expensive imported Western medicines. To be a good person often related to filial obligations and proper care of ancestors, through care and practices in spaces with altars and tombs. By aligning environmental conditions properly, families could ensure peaceful relations with both spirits and ancestors, granting themselves and the previous generation a sense of comfort and ongoing social relations through worship.

Patriotism in particular as a source of identity formation has not been explored as explicitly in the CES literature, although sense 
of national pride in certain production landscapes or environments has been mentioned in some studies (Todd 2013, Hirons et al. 2016). In Vietnam, specific places have been intimately connected to the history and memory of multiple conflicts throughout the 20th century; the association of some sites with particular figures, or as sites of particular revolutionary battles, are commonplace across the country (Biggs 2005). A number of these sites combine important historical commemorations with preservation of environmental services. Such examples include Pác Bó cave (a karst landscape in the Northern mountains that provided shelter to Ho Chi Minh as he was planning anti-colonial military strategies, now preserved as a tourist site), the U Minh Forest (a wetland hideout during the US war that is now a National Park), and the Cave of the Eight Girls (a memorial site in Quảng Bình province where eight youth working on the Ho Chi Minh Highway were buried alive in 1972). The protection of these sites of cultural heritage (di sản văn hóa) was mandated in the 1992 Constitution, including "legacies of history, the revolution, cultural relics, artistic works, and famous landscapes." Within Hà Tĩnh, landscapes reflected links to revolutionary work through commemorations of historical figures and visits to their memorials.

Thus, there is an important role for historical memory and celebrations of patriotism and nationalism to be included as a potential CES that bring people satisfaction and well-being from experiencing particular landscapes. Given that this has been a relatively neglected topic, it could be a useful focus to bring more people into contact with CES and provide justifications for improved management (such as standards for conservation or harnessed for recreation and tourism). Such an effort would also contribute to breaking down the artificial divide between nature and culture that is typical of many protected areas, in which only natural elements are emphasized as worthy of attention (Fall 2002, Byrne et al. 2013). This has happened in Vietnam as well, when a category of cultural, historical, and environmental reserves was eliminated from the protected areas system in the 1990 s as biodiversity protection became a guiding mandate instead (McElwee 2002).

In Table 3, we outline how the different CES in the field sites combined both tangible and intangible benefits derived from a variety of man-made and natural landscapes, and which have contributed to generating experiences, identifies, and capabilities in myriad ways, often associated with other provisioning or regulating ecosystem services as well. Such findings reinforce the point that CES are context dependent, and often difficult to classify in ways that are broadly generalizable or in isolation from other forms of ES (Gould and Lincoln 2017, Lyver et al. 2017).

\section{Impacts of social change over time}

To have fine brown trousers and a conical hat in the pre-war era conveyed a rich sense of identity as Vietnamese; now, such identities are more likely to be conveyed from watching TV shows. Changes in social norms related to identity formation are a constant part of culture and not a static a priori condition. Thus, change in CES formation and attention to CES valuation as a process needs to be a part of the literature as well (Gould et al. 2020). Such change can be driven by multiple factors; for example, the erosion of traditional crops and foods, despite being preferred for many cultural benefits, has been documented around the globe, driven partially by exogenous factors like trade, but also internally by shifting value structures (Zimmerer 2014, Ficiciyan et al. 2018). As well, these changes can be seen in Vietnam through a rapid shift from mostly traditional varieties of rice grown in 1980 to current use of mostly high-yielding seeds (Trần and Kajisa 2006). Although traditional seeds persist as supplements to these modern varieties, particularly where risk spreading is important as it was in Hà Tĩnh, their production has declined precipitously. Such changes have meant that cultural identity, aesthetics, and knowledge systems related to rice landscapes are negatively correlated with an increase in agricultural modernization (Tekken et al. 2017).

The long-term effects of labor migration are also likely to have an impact on CES knowledge and use. This phenomenon was recent enough in 2019 that there was only a preliminary sense of the issue from respondents, particularly around whether or not generations who spent years away from home would be able retain a sense of place, and that local ecological and agricultural knowledge was likely to decrease among younger generations. These concerns were seen as likely to accelerate because there was a perceived demand for continued labor migration. However, after the re-survey in July 2019, a major international incident occurred in October 2019, in which 39 young people from Hà Tĩnh were found in a lorry in the UK, dead from suffocation in a labor smuggling operation (Peltier and Specia 2019). The wellpublicized incident may serve to reduce the allure of labor migration for some in the province, but will need to be investigated further, particularly regarding migration's effects on CES perception and use.

\section{Linking cultural ecosystem services (CES) to improved overall environmental management}

Understanding local use and valuation of CES can help in the management and governance of different landscapes; as Pascua et al. (2017:466) noted, "identifying CES in an accurate and culturally appropriate way is vital in resource management efforts, particularly if they can make place-based values visible before important decisions are made." Many CES studies have thus tried to find commensurable ways to measure and value CES so that they might be compared to other services or presented as reasons to avoid development harmful to ecosystems (Hirons et al. 2016). Although this study did not attempt to systematically value the different CES encountered, future studies could do so, particularly given the fact that Vietnam does have a payment for environmental services policy nationwide. Because one of the five main services that are eligible for payments includes aesthetic landscape values for tourism, improved valuation in this area could provide tangible financial benefits to local areas.

In addition to PES payments, tourism promotion in Vietnam could make better use of CES, capitalizing on patriotism and sense of place, and take advantage of opportunities to combine cultural and environmental tourism, which to date have been treated separately. Much ecotourism has been promoted to international visitors while cultural heritage has been mostly domestic, yet there are potential opportunities to combine both through attention to CES (Thào and Pulliat 2019). For example, UNESCO World Heritage recognition has been granted to different intangible cultures in Vietnam, including folk songs and Mother goddess religion, thus encouraging tourism and visits to 
Table 3. Overview of types and categories of important cultural ecosystem services (CES) in central Vietnam. Note: KGNR = Kẻ Gỗ Nature Reserve.

\begin{tabular}{|c|c|c|c|c|c|c|}
\hline Categories & Type of benefit & $\begin{array}{l}\text { Values associated } \\
\text { with CES }\end{array}$ & $\begin{array}{l}\text { Landscapes in which } \\
\text { take place }\end{array}$ & Experiences, identities, and capabilities & $\begin{array}{l}\text { Other ES } \\
\text { associated }\end{array}$ & Shifts over time \\
\hline $\begin{array}{l}\text { Agricultural } \\
\text { production }\end{array}$ & Material & $\begin{array}{l}\text { Sense of security } \\
\text { Health and well- } \\
\text { being } \\
\text { Generational } \\
\text { identity } \\
\text { Social and } \\
\text { community bonds } \\
\text { Financial "bank } \\
\text { account" } \\
\text { Cultural } \\
\text { production (songs) }\end{array}$ & $\begin{array}{l}\text { Man-made } \\
\text { agroecosystems (rice } \\
\text { fields and home } \\
\text { gardens) }\end{array}$ & $\begin{array}{l}\text { Experiences: hard work in farming, } \\
\text { pleasure in eating } \\
\text { Identities: sense of community } \\
\text { through shared labor and shared } \\
\text { produce/meals } \\
\text { Capabilities: sense of food security } \\
\text { and financial security }\end{array}$ & $\begin{array}{l}\text { Provisioning } \\
\text { services for food } \\
\text { Soil services } \\
\text { Water services } \\
\text { Genetic diversity in } \\
\text { local seeds }\end{array}$ & $\begin{array}{l}\text { No declines in } \% \text { of } \\
\text { household farming rice, but } \\
\text { declines in use of local } \\
\text { varieties } \\
\text { Shifts away from gardens as } \\
\text { source of income, replaced } \\
\text { by remittances }\end{array}$ \\
\hline $\begin{array}{l}\text { Medicinal plant } \\
\text { use }\end{array}$ & Material & $\begin{array}{l}\text { Sense of } \\
\text { independence } \\
\text { Health and well- } \\
\text { being } \\
\text { Supplementary } \\
\text { food for meals } \\
\text { Financial "bank } \\
\text { account" }\end{array}$ & $\begin{array}{l}\text { Man-made } \\
\text { agroecosystems } \\
\text { (home gardens) } \\
\text { Natural forests of } \\
\text { KGNR }\end{array}$ & $\begin{array}{l}\text { Experiences: learning about medicinal } \\
\text { plants, looking for them in forest } \\
\text { Identities: intergenerational } \\
\text { transmission of knowledge } \\
\text { Capabilities: self-sufficient from } \\
\text { medical system }\end{array}$ & Genetic diversity & $\begin{array}{l}\text { Decline in availability of } \\
\text { wild-crafted medicinals due } \\
\text { to over-harvesting } \\
\text { Loss of knowledge among } \\
\text { younger generation }\end{array}$ \\
\hline Craft materials & Material & $\begin{array}{l}\text { Cultural identity } \\
\text { Financial "bank } \\
\text { account" }\end{array}$ & $\begin{array}{l}\text { Natural forests of } \\
\text { KGNR } \\
\text { Man-made } \\
\text { agroecosystems } \\
\text { (home gardens) }\end{array}$ & $\begin{array}{l}\text { Experiences: time spent in forest, } \\
\text { opportunities to learn about forest } \\
\text { Identities: having clothes that reflect } \\
\text { Vietnamese identity } \\
\text { Capabilities: } \\
\text { financial flexibility for women }\end{array}$ & Genetic diversity & $\begin{array}{l}\text { Decline in demands for dyes } \\
\text { due to changing dress } \\
\text { norms } \\
\text { Decline in collection of } \\
\text { palm leaves; replaced by } \\
\text { remittances }\end{array}$ \\
\hline Sense of place & Non-material & $\begin{array}{l}\text { Pride in homeland } \\
\text { Rural/farming } \\
\text { identity } \\
\text { Ties to historical } \\
\text { lineages and } \\
\text { figures } \\
\text { Learning about } \\
\text { history } \\
\text { Patriotism and } \\
\text { nationalism } \\
\text { Aesthetics }\end{array}$ & $\begin{array}{l}\text { Natural and man- } \\
\text { made landscapes, } \\
\text { including villages, } \\
\text { Lake Kẻ Gố, } \\
\text { memorials and } \\
\text { tombs }\end{array}$ & $\begin{array}{l}\text { Experiences: visiting local memorials, } \\
\text { learning about personages, enjoying } \\
\text { recreation opportunities } \\
\text { Identities: being part of ancestral } \\
\text { homeland, feeling part of Vietnamese } \\
\text { nation } \\
\text { Capabilities: thriving in familiar area }\end{array}$ & $\begin{array}{l}\text { Water provisioning } \\
\text { Provisioning } \\
\text { services for food }\end{array}$ & $\begin{array}{l}\text { Ties to homeland have } \\
\text { remained strong, although } \\
\text { overseas labor migration } \\
\text { among youth is cause for } \\
\text { concern }\end{array}$ \\
\hline $\begin{array}{l}\text { Spirituality and } \\
\text { religious } \\
\text { practices }\end{array}$ & Non-material & $\begin{array}{l}\text { Ties to ancestors } \\
\text { Safety from bad } \\
\text { spirits } \\
\text { Historical learning } \\
\text { "Right" and moral } \\
\text { living }\end{array}$ & $\begin{array}{l}\text { Natural forests } \\
\text { Man-made gardens } \\
\text { Man-made altars } \\
\text { and tombs }\end{array}$ & $\begin{array}{l}\text { Experiences: building and praying at } \\
\text { altars and tombs } \\
\text { Identities: being part of family and } \\
\text { filial piety } \\
\text { Capabilities: living correctly with } \\
\text { spirits and ancestors }\end{array}$ & $\begin{array}{l}\text { Habitat and } \\
\text { biodiversity (in } \\
\text { natural forests near } \\
\text { shrines) }\end{array}$ & $\begin{array}{l}\text { Decline in formal religious } \\
\text { buildings and practices } \\
\text { when discouraged by state } \\
\text { Re-vitalization of religion } \\
\text { and pilgrimage travel more } \\
\text { recently }\end{array}$ \\
\hline $\begin{array}{l}\text { Aesthetics, } \\
\text { recreation, and } \\
\text { health }\end{array}$ & Non-material & $\begin{array}{l}\text { Healthy } \\
\text { environment } \\
\text { Places for fun and } \\
\text { recreation } \\
\text { Shade and cooling } \\
\text { Aesthetic } \\
\text { appreciation } \\
\text { Calm and } \\
\text { peacefulness }\end{array}$ & $\begin{array}{l}\text { Natural and man- } \\
\text { made forests } \\
\text { Man-made water } \\
\text { bodies } \\
\text { Man-made gardens }\end{array}$ & $\begin{array}{l}\text { Experiences: enjoying the outdoors, } \\
\text { listening to birdsong } \\
\text { Identities: satisfaction with being part } \\
\text { of community } \\
\text { Capabilities: having well-being in } \\
\text { comfortable surroundings }\end{array}$ & $\begin{array}{l}\text { Pollination services } \\
\text { (ornamental } \\
\text { flowers) }\end{array}$ & $\begin{array}{l}\text { Increasing time and } \\
\text { disposable income for } \\
\text { recreation services and } \\
\text { travel } \\
\text { Expansion of shelterbelts } \\
\text { and trees through acacia } \\
\text { plantings }\end{array}$ \\
\hline
\end{tabular}


sites of interest and linking them to protection of or engagement in specific landscapes could acknowledge the CES associated with this heritage.

New alternative CES-based valuations and sources of income could also counter other economic development schemes causing damage to the local environment; according to local residents, the province had tried to invest in a cattle feedlot operation during the 2010s. Local people strongly disliked the operation, stating that it was highly polluting, particularly with regard to air and water, and it had been shut down prior to our visit in 2019 due to local complaints. It is possible that better valuation of environmental services and CES benefits might have provided an alternative to this environmentally degrading decision made by provincial officials.

\section{CONCLUSION}

Our study has been one of the first to explore the many facets of CES in Vietnam, and we followed calls to examine them "from the perspective of peoples' interactions with, and understandings of places, localities, landscapes and species" (Fish et al. 2016:209), rather than beginning with fixed CES categories. Our work has confirmed that many values that are culturally specific or place based are not always captured in the categories in common use, including pride in native places, ties to ancestors and creation of filial identities, and reflections of patriotic and nationalistic feelings. We also noted the importance of historical memory for the provisioning of CES and urge future research in this area.

As we have also noted, the predominant tendency to associate CES only with non-material benefits presents a false divide: many benefits relating to identities, experiences, and capabilities derive from both material and non-material interactions with nature. Many material and consumptive ecosystem services have cultural components and are managed by values that are worthy of attention; thus, not only intangible benefits should be considered CES. It is also important to remember that a variety of landscapes, both natural and produced, provide bundles of CES, which have the potential to provide alternative trajectories of economic development.

Finally, by tracking CES over time, we can also see that ecosystem benefits are not static and can change in response to both ecosystem shifts and social transformations. This topic needs more attention in the CES literature, both with regard to how shifts in ecosystem state impact the availability of CES, as well as how global trends like migration and international trade may drive CES valuation away from historical baselines. There is also considerable room for improvement with regard to policy and management of CES to ensure that these shifting values are reflected in the ways in which environments are governed and managed.

Responses to this article can be read online at: https://www.ecologyandsociety.org/issues/responses. $\mathrm{php} / 12615$

\section{Author Contributions:}

Author contributions: PM conducted the fieldwork in 2001 and 2019 and wrote the article; $H$. Vũ assisted with fieldwork and writing in 2019; G. Võ assisted with fieldwork in 2001 and 2019; D. Lê did data entry in 2019.

\section{Acknowledgments:}

We thank the Central Institute for Natural Resources and Environmental Studies of Vietnam National University and its current director, Dr. Lữu Thế Anh, and previous directors, Dr. Hoàng Văn Thắng, Dr. Trương Quang Học, and the late Dr. Võ Quy, for support of this research project over the past two decades. The assistance of Mr. Trần Văn Sinh in supporting the fieldwork in 2001 is gratefully acknowledged. Funding for this work for PM has come from a National Science Foundation (NSF) Doctoral Dissertation Fellowship (BCS-0108992), from the Carnegie Corporation, and from NSF grant 1853759, "Understanding the Use of Ecosystem Services Concepts in Environmental Policy." The work undertaken with human subjects was approved by Institutional Review Boards at Yale University in 2000 and Rutgers University in 2019 (\#Pro2019000556).

\section{Data Availability:}

The household survey data that support the findings of this study are available on request from the corresponding author. The data are not publicly available because they were collected from households and contain personal information.

\section{LITERATURE CITED}

Appadurai, A. 1988. The social life of things: commodities in cultural perspective. Cambridge University Press, Cambridge, UK. https://doi.org/10.1017/CBO9780511819582

Århem, N. 2009. In the sacred forest: landscape, livelihood and spirit beliefs among the Katu of Vietnam. University of Gothenburg Department of Social Anthropology, Gothenburg, Sweden. [online] URL: https://www.academia.edu/10640092/ In the Sacred Forest Landscape livelihood and spirit beliefsamong the Katu of Vietnam

Berg, H., A. Söderholm, A. Söderström, and T. T. Nguyễn. 2017. Recognizing wetland ecosystem services for sustainable rice farming in the Mekong Delta, Vietnam. Sustainability Science 12 (1):137-154. https://dx.doi.org/10.1007/s11625-016-0409-x

Biggs, D. 2005. Managing a rebel landscape: conservation, pioneers, and the revolutionary past in the U Minh Forest, Vietnam. Environmental History 10(3):448-476. https://doi. org/10.1093/envhis/10.3.448

Bryce, R., K. N. Irvine, A. Church, R. Fish, S. Ranger, and J. O. Kenter. 2016. Subjective well-being indicators for large-scale assessment of cultural ecosystem services. Ecosystem Services 21:258-269. https://doi.org/10.1016/j.ecoser.2016.07.015

Bùi, C. H. 1999. Integration of traditional medicine into the health care system. Pages 29-36 in B. C. Hoàng, T. Phó, and N. 
Hữu, editors. Vietnamese traditional medicine. Thế Giới Publishers, Hanoi, Vietnam.

Bùi, H. T., T.-A. Lê, and P.-D. Ngô. 2018. Managing UNESCO World Heritage in Vietnam: visitor evaluation of heritage mission and management of Tràng An Landscape Complex. Pages 89-105 in Y. Wang, A. Shakeela, A. Kwek, and C. Khoo-Lattimore, editors. Managing Asian destinations. Springer, Singapore. https://doi.org/10.1007/978-981-10-8426-3 6

Bùi, T. 2000. Từ Điển Hà Tĩnh [Dictionary of Hà Tĩnh]. NXB Sở Văn Hoá Thông Tin Hà Tĩnh, Hà Tĩnh, Vietnam.

Byrne, D. R., S. Brockwell, and S. O'Connor. 2013. Introduction: engaging culture and nature. Pages 1-12 in S. Brockwell, S. O'Connor, and D. Byrne, editors. Transcending the culture-nature divide in cultural heritage: views from the Asia-Pacific region. Australian National University Press, Canberra, Australia. [online] URL: https://www.jstor.org/stable/pdf/j.ctt5hgz2n.4. pdf?refreqid $=$ excelsior $\% 3$ Adecd6ecde08412ade36d3718991def6a

Chan, K. M. A., T. Satterfield, and J. Goldstein. 2012. Rethinking ecosystem services to better address and navigate cultural values. Ecological Economics 74:8-18. https://doi.org/10.1016/j. ecolecon.2011.11.011

Condominas, G. 1974. We have eaten the forest: the story of a montagnard village in the Central Highlands of Vietnam. Hill and Wang, New York, New York, USA.

Cormier-Salem, M.-C., N. V. Trai, A. Burgos, J.-D. Durand, Y. Bettarel, J. Klein, H. D. Huy, and J. Panfili. 2017. The mangrove's contribution to people: interdisciplinary pilot study of the Can Gio Mangrove Biosphere Reserve in Viet Nam. Comptes Rendus Geoscience 349(6-7):341-350. https://doi.org/10.1016/j.crte.2017.09.001

Daniel, T. C., A. Muhar, A. Arnberger, O. Aznar, J. W. Boyd, K. M. A. Chan, R. Costanza, T. Elmqvist, C. G. Flint, P. H. Gobster, A. Grêt-Regamey, R. Lave, S. Muhar, M. Penker, R. G. Ribe, T. Schauppenlehner, T. Sikor, I. Soloviy, M. Spierenburg, K. Taczanowska, J. Tam, and A. von der Dunk. 2012. Contributions of cultural services to the ecosystem services agenda. Proceedings of the National Academy of Sciences 109(23):8812-8819. https:// doi.org/10.1073/pnas.1114773109

Đào, V. H. 1998. Hát ví Nghệ Tĩnh (Ví Singing of Nghệ Tĩnh). Music Publishing House, Hanoi, Vietnam.

Díaz, S., U. Pascual, M. Stenseke, B. Martín-López, R. T. Watson, Z. Molnár, R. Hill, K. M. A. Chan, I. A. Baste, K. A. Brauman, S. Polasky, A. Church, M. Lonsdale, A. Larigauderie, P. W. Leadley, A. P. E. van Oudenhoven, F. van der Plaat, M. Schröter, S. Lavorel, Y. Aumeeruddy-Thomas, E. Bukvareva, K. Davies, S. Demissew, G. Erpul, P. Failler, C. A. Guerra, C. L. Hewitt, H. Keune, S. Lindley, and Y. Shirayama. 2018. Assessing nature's contributions to people. Science 359(6373):270-272. https://doi. org/10.1126/science.aap8826

Fall, J. 2002. Divide and rule: constructing human boundaries in 'boundless nature.' GeoJournal 58:243-251. https://doi. org/10.1023/B:GEJO.0000017955.72829.15

Ficiciyan, A., J. Loos, S. Sievers-Glotzbach and T. Tscharntke. 2018. More than yield: ecosystem services of traditional versus modern crop varieties revisited. Sustainability 10(8):2834. https:// doi.org/10.3390/su10082834

Fish, R., A. Church, and M. Winter. 2016. Conceptualising cultural ecosystem services: a novel framework for research and critical engagement. Ecosystem Services 21:208-217. https://doi. org/10.1016/j.ecoser.2016.09.002

Gould, R. K., and N. K. Lincoln. 2017. Expanding the suite of cultural ecosystem services to include ingenuity, perspective, and life teaching. Ecosystem Services 25:117-127. https://doi. org/10.1016/j.ecoser.2017.04.002

Gould, R. K., J. W. Morse, and A. B. Adams. 2019. Cultural ecosystem services and decision-making: how researchers describe the applications of their work. People and Nature 1:457-475. https://doi.org/10.1002/pan3.10044

Gould, R. K., L. L. Bremer, P. Pascua, and K. Meza-Prado. 2020. Frontiers in cultural ecosystem services: toward greater equity and justice in ecosystem services research and practice. BioScience 70:1093-1107. https://doi.org/10.1093/biosci/biaa112

Hardy, A. 2003. Architects of a discourse? Scholars, migrants and the notion of home in Vietnam. Pages 301-320 in B. S. A. Yeoh, M. W. Charney, and T. C. Kiong, editors. Approaching transnationalisms: studies on transnational societies, multicultural contacts, and imaginings of home. Springer, Boston, Massachusetts, USA. https://doi.org/10.1007/978-1-4419-9220-8 13>

Henderson, A. J., and C. D. Bacon. 2011. Lanonia (Arecaceae: Palmae), a new genus from Asia, with a revision of the species. Systematic Botany 36:883-895. https://doi.org/10.1600/036364411X604903

Hirons, M., C. Comberti, and R. Dunford. 2016. Valuing cultural ecosystem services. Annual Review of Environment and Resources 41(1):545-574. https://doi.org/10.1146/annurevenviron-110615-085831

Hồ, H. L., T. J. Ballatore, K. N. Irvine, T. H. D. Nguyễn, T. C. T. Trương, and S. Yoshihisa. 2018b. Socio-geographic indicators to evaluate landscape cultural ecosystem services: a case of Mekong Delta, Vietnam. Ecosystem Services 31:527-542. https://doi. org/10.1016/j.ecoser.2017.11.003

Hồ, H. L., T. H. D. Nguyễn, T. T. Võ, and S. Yoshihisa. 2018a. An analytical approach in accounting for social values of ecosystem services in a Ramsar site: a case study in the Mekong Delta, Vietnam. Ecological Indicators 89:118-129. https://dx.doi. org/10.1016/j.ecolind.2017.12.066

James, S. P. 2015. Cultural ecosystem services: a critical assessment. Ethics, Policy and Environment 18(3):338-350. https://doi.org/10.1080/21550085.2015.1111616

Karis, T. 2013. Unofficial Hanoians: migration, native place and urban citizenship in Vietnam. Asia Pacific Journal of Anthropology 14:256-273 https://doi.org/10.1080/14442213.2013.794156

Kirchhoff, T. 2019. Abandoning the concept of cultural ecosystem services, or against natural-scientific imperialism. BioScience 69(3):220-227. https://doi.org/10.1093/biosci/biz007

Kosanic, A., and J. Petzold. 2020. A systematic review of cultural ecosystem services and human wellbeing. Ecosystem Services 45:101168. https://doi.org/10.1016/j.ecoser.2020.101168 
Lã, N. K., T. T. Nguyễn, X. G. Nguyễn, X. V. Nguyễn, and X. H. Nguyễn. 2016. Phân tích đạc điểm và nguyên nhân diê̂n biến tài nguyên rừng tỉnh Hà Tĩnh, giải đoạn 1995-2014. Tạp Chí Khoa Học và Công Nghệ Lâm Nghiệp 6:71-81.

Lê, T. C. 1999. Vietnam: traditional cultural concepts of human relations with the natural environment. Asian Geographer 18 (1-2):67-74. https://doi.org/10.1080/10225706.1999.9684048

Lyver, P. O., P. Timoti, A. M. Gormley, C. J. Jones, S. J. Richardson, B. L. Tahi, and S. Greenhalgh. 2017. Key Mâori values strengthen the mapping of forest ecosystem services. Ecosystem Services 27:92-102. https://doi.org/10.1016/j.ecoser.2017.08.009

McDonough, S., W. Gallardo, H. Berg, N. V. Trai, and N. Q. Yên. 2014. Wetland ecosystem service values and shrimp aquaculture relationships in Can Gio, Vietnam. Ecological Indicators 46:201-213. https://doi.org/10.1016/j.ecolind.2014.06.012

McElwee, P. D. 2002. Lost worlds and local people: Protected areas development in Vietnam. Pages 312-329 in D. Chatty and M. Colchester, editors. Conservation and Mobile Indigenous Peoples: Displacement, Forced Settlement, and Sustainable Development. Berghanh Press, Oxford, UK.

McElwee, P. D. 2007. From the moral economy to the world economy: revisiting Vietnamese peasants in a globalizing era. Journal of Vietnamese Studies 2(2):57-107. https://doi. org/10.1525/vs.2007.2.2.57

McElwee, P. D. 2008. Forest environmental income in Vietnam: household socioeconomic factors influencing forest use. Environmental Conservation 35(2):147-159. https://doi.org/10.1017/ $\underline{\mathrm{S} 0376892908004736}$

McElwee, P. D. 2010. Resource use among rural agricultural households near protected areas in Vietnam: The social costs of conservation and implications for enforcement. Environmental Management 45(1):113-131. https://doi.org/10.1007/s00267-009-9394-5

McElwee, P., B. Huber, and T. H. V. Nguyễn. 2019. Hybrid outcomes of payments for ecosystem services policies in Vietnam: between theory and practice. Development and Change 51 (1):253-280. https://doi.org/10.1111/dech.12548

Milcu, A. I., J. Hanspach, D. Abson, and J. Fischer. 2013. Cultural ecosystem services: a literature review and prospects for future research. Ecology and Society 18(3):44. https://doi.org/10.5751/ ES-05790-180344

Millennium Ecosystem Assessment (MEA). 2005. Ecosystems and human well-being: our human planet: summary for decision makers. Island, Washington, D.C., USA.

Mohri, H., S. Lahoti, O. Saito, A. Mahalingam, N. Gunatilleke, Irham, V. T. Hoang, G. Hitinayake, K. Takeuchi, and S. Herath. 2013. Assessment of ecosystem services in homegarden systems in Indonesia, Sri Lanka, and Vietnam. Ecosystem Services 5:124-136. https://doi.org/10.1016/j.ecoser.2013.07.006

Nguyễn, T. H., and A. Ross. 2017. Barriers and opportunities for the involvement of indigenous knowledge in water resources management in the Gâm river basin in North-East Vietnam. Water Alternatives 10(1):134-159. [online] URL: https://www. water-alternatives.org/index.php/alldoc/articles/vol10/v10issue1/346a10-1-8/file
Parnwell, M. J. G. 2013. Whale worship and tourism development in the Hồi An-Dà Nẫng corridor, Việt Nam. South East Asia Research 21(3):475-496. https://doi.org/10.5367/sear.2013.0162

Pascua, P., H. McMillen, T. Ticktin, M. Vaughan, and K. B. Winter. 2017. Beyond services: a process and framework to incorporate cultural, genealogical, place-based, and indigenous relationships in ecosystem service assessments. Ecosystem Services 26:465-475. https://doi.org/10.1016/j.ecoser.2017.03.012

Peltier, E., and M. Specia. 2019. UK police trace fatal journey after 39 bodies found in truck. New York Times, 19 October. [online] URL: https://www.nytimes.com/2019/10/23/world/europe/ bodies-found-truck-essex.html

Phạm, T. M. T. 2018. Dạy học hát dân ca ví, giặm nghệ tĩnh tại trường cao đẳng văn hóa Nghệ thuật Nghệ An [Teaching Ví and Giặm folk songs at the College of Culture and Arts, Nghe An]. Thesis. National University of Art Education, Hanoi, Vietnam.

Pleasant, M. M., S. A. Gray, C. Lepczyk, A. Fernandes, N. Hunter, and D. Ford. 2014. Managing cultural ecosystem services. Ecosystem Services 8:141-147. https://doi.org/10.1016/j.ecoser.2014.03.006

Plieninger, T., C. Bieling, N. Fagerholm, A. Byg, T. Hartel, P. Hurley, C. A. López-Santiago, N. Nagabhatla, E. Oteros-Rozas, C. M. Raymond, D. van der Horst, and L. Huntsinger. 2015. The role of cultural ecosystem services in landscape management and planning. Current Opinion in Environmental Sustainability 14 (C):28-33. https://doi.org/10.1016/j.cosust.2015.02.006

Pröpper, M., and F. Haupts. 2014. The culturality of ecosystem services. Emphasizing process and transformation. Ecological Economics 108:28-35. https://doi.org/10.1016/j.ecolecon.2014.09.023

Quyên, N. T. K., H. Berg, W. Gallardo, and T. D. Châu 2017. Stakeholders' perceptions of ecosystem services and Pangasius catfish farming development along the Hau River in the Mekong Delta, Vietnam. Ecosystem Services 25:2-14. https://dx.doi. org/10.1016/j.ecoser.2017.03.007

Roux, D. J., M. K. S. Smith, I. P. J. Smit, S. Freitag, L. Slabbert, M. M. Mokhatla, J. Hayes, and N. P. Mpapane. 2020. Cultural ecosystem services as complex outcomes of people-nature interactions in protected areas. Ecosystem Services 43:101111. https://doi.org/10.1016/j.ecoser.2020.101111

Russell, R., A. D. Guerry, P. Balvanera, R. K. Gould, X. Basurto, K. M. A. Chan, S. Klain, J. Levine, and J. Tam. 2013. Humans and Nature: how knowing and experiencing Nature affect wellbeing. Annual Review of Environment and Resources 38(1):473502. https://doi.org/10.1146/annurev-environ-012312-110838

Satz, D., R. K. Gould, K. M. A. Chan, A. Guerry, B. Norton, T. Satterfield, B. S. Halpern, J. Levine, U. Woodside, N. Hannahs, X. Basurto, and S. Klain. 2013. The challenges of incorporating cultural ecosystem services into environmental assessment. Ambio 42(6):675-684. https://doi.org/10.1007/s13280-013-0386-6

Schnegg, M., R. Rieprich, and M. Pröpper. 2014. Culture, nature, and the valuation of ecosystem services in northern Namibia. Ecology and Society 19(4):26. https://doi.org/10.5751/ES-06896-190426 
Sơn, H. N., D. T. L. Chi, and A. Kingsbury. 2019. Indigenous knowledge and climate change adaptation of ethnic minorities in the mountainous regions of Vietnam: a case study of the Yao people in Bac Kan Province. Agricultural Systems 176:102683. https://doi.org/10.1016/j.agsy.2019.102683

Tekken, V., J. H. Spangenberg, B. Burkhard, M. Escalada, S. StollKleemann, D. T. Trương, and J. Settele. 2017. "Things are different now": farmer perceptions of cultural ecosystem services of traditional rice landscapes in Vietnam and the Philippines. Ecosystem Services 25:153-166. https://dx.doi.org/10.1016/j. ecoser.2017.04.010

Tengberg, A., S. Fredholm, I. Eliasson, I. Knez, K. Saltzman, and O. Wetterberg. 2012. Cultural ecosystem services provided by landscapes: Assessment of heritage values and identity. Ecosystem Services 2:14-26. https://doi.org/10.1016/j.ecoser.2012.07.006

Thào, H., and G. Pulliat. 2019. Green for whom? Exploring ecotourism as a climate-adaptation strategy in Tràng An, Vietnam. Pages 179-199 in A. G. Daniere and M. Garschagen, editors. Urban climate resilience in Southeast Asia. Springer, Dordrecht, The Netherlands. https://doi.org/10.1007/978-3-319-98968-6 9

Todd, A. M. 2013. Communicating environmental patriotism: a rhetorical history of the American environmental movement. Routledge, New York, New York, USA.

Trần, N. L., and H. B. Phạm. 2000. Kết quả nghiên cứu da dạ_ng thực vật lâm sản ngoại gỗ tại Cẩm Mỹ (Hà Tĩnh). Trung Tâm Nghiên Cứu Tài Nguyên và Môi Trường (CRES), Hanoi, Vietnam.

Trần, T. U., and K. Kajisa. 2006. The impact of green revolution on rice production in Vietnam. Developing Economies 44 (2):167-189. https://doi.org/10.1111/j.1746-1049.2006.00012.x

Trình, L. N., J. W. Watson, N. N. Huệ, N. N. Dệ, N. V. Minh, P. T. Chữ, B. R. Sthapit, and P. B. Eyzaguirre. 2003. Agrobiodiversity conservation and development in Vietnamese home gardens. Agriculture, Ecosystems and Environment 97(1-3):317-344. https://doi.org/10.1016/S0167-8809(02)00228-1

UNESCO. 2014. Nomination file No. 01008 for inscription on the representative list of the intangible cultural heritage of humanity in 2014: Ví and Giặm folk songs of Nghệ Tĩnh. United Nations Economic Social and Cultural Organization, Paris, France. [online] URL: https://ich.unesco.org/en/RL/v-and-gimfolk-songs-of-ngh-tnh-01008

Vlkova, M., Z. Polesny, V. Verner, J. Banout, M. Dvorak, J. Havlik, B. Lojka, P. Ehl, and J. Krausova. 2011. Ethnobotanical knowledge and agrobiodiversity in subsistence farming: case study of home gardens in Phong My commune, central Vietnam. Genetic Resources and Crop Evolution 58(5):629-644. https://doi. org/10.1007/s10722-010-9603-3

von Heland, J., and C. Folke. 2014. A social contract with the ancestors-culture and ecosystem services in southern Madagascar. Global Environmental Change 24:251-264. https:// doi.org/10.1016/j.gloenvcha.2013.11.003
Wolff, S., C. J. E. Schulp, and P. H. Verburg. 2015. Mapping ecosystem services demand: a review of current research and future perspectives. Ecological Indicators 55:159-171. https://doi. org/10.1016/j.ecolind.2015.03.016

Zimmerer, K. S. 2014. Conserving agrobiodiversity amid global change, migration, and nontraditional livelihood networks: the dynamic uses of cultural landscape knowledge. Ecology and Society 19(2):1. http://dx.doi.org/10.5751/ES-06316-190201 